\title{
Musical chairs in science policy
}

As talk of changes at the highest levels of French government grew last month, the country's directors of research were already a few steps ahead. A Correspondent reports

THF directors of French scientific and technical research have recently been involuntary participants in a game of musical chairs organised by the government. First, the president of the Centre National d'Etudes Spatiales (CNES), Professor Maurice Lévy, was dismissed by the Minister of Industry and Rescarch, M Michel d'Ornano, for making concessions to striking staff that his assistant had refused to grant in his absence. He has yet to find another post. On the same day, Professor Curien, head of the Department of Scientific and Technical Research (DGRST), replaced Professor Lévy. The move, from a department which coordinates and implements all research policies (except military projects) to a directly operational post, has drawn much comment.

$\Lambda$ few days later, Professor Curien, who was director of the Centre National de la Recherche Scientifique (CNRS) until 1973, was replaced at the head of the DGRST by Professor Grégory, who had previously taken bis place at the CNRS. Then, to complete these acrobatics, which incidentally only involved physicists, the director of physics at the CNRS, Professor Chabbal, became director-general of the CNRS at the beginning of August.

The government-and in particular M d'Ornano-has shown in this series of decisions an unexpected authority and haste at a time when the credibility of those in power is constantly weakening. The circumstances of the CNES affair are fairly clear. The shrewd and effective Professor Lévy was forced to leave because of the Minister's change of mood-a change which neither his colleagues nor his advisers, who saw the opportunity to bring about other changes, sought to influence. A review of the allocation of the space budget between the programmes of the European Space Agency and the French programme had been due since European agreement on the level of the Agency's activities. The new allocation brought about some changes in the CNES budget which were to make some of its staff redundant, particularly at Toulouse.

With France wanting to guarantee Europe's autonomy regarding applications satellites, especially telecommuni- cations (the last breath of the great Gaullist doctrine of independence), the CNES gave priority to completing the launcher Ariane. (The Ariane project's director, Yves Sillard, became director of the CNES and assistant to the President a few weeks ago.) Under the threat of redundancies, CNES workers went on strike. The CNES directors were unwilling to give in to the strikers' demands, and maintained their position for several days, only to be overruled in the end by their president, who took the side of the employees. The government, however, intervened.

The causes of the stir this provoked in the research policy establishment are more complex. Two main characteristics differentiate research in France from research in other countries. The arrangement in the universities, where there is an even split between research and teaching, is unsatisfactory; information about what is going on does not permit either good financial management or national coordination. In accordance with the recommendations of the VIIth Plan, the Secretary of State for the Universities, who is responsible for university research and the CNRS, has created a "Research Mission" directed by Professor Denisse, who was Professor Lévy's predecessor as president of the CNES. The purpose of this mission is to re-organise university research.

The other characteristic of French research is the endemic weakness of industrial and technical research. French industry does not spend enough money on research, as $\mathbf{M}$ d'Ornano recently pointed out in parliament. Moreover, public funds normally allocated to industrial research are often put to other uses financing industry. The DGRST, which is for the most part made up of specialists in basic research and is directed by a laboratory physicist, often has great difficulty understanding industrial problems. This results in disagreements with other administrative departments concerned with industry, technology and financial management.

Thus the DGRST often ends up giving its funds (FF640 million in 1976) to the same laboratories. In an attempt to resolve this problem $\mathrm{M}$ d'Ornano asked the fiery director of the Centre National d'Etudes des Telecommunications (CNET) for a report on industrial research last April. One of the conclusions of the report was that a subdepartment of industrial research and technology should be set up, linked to the Department of Research.

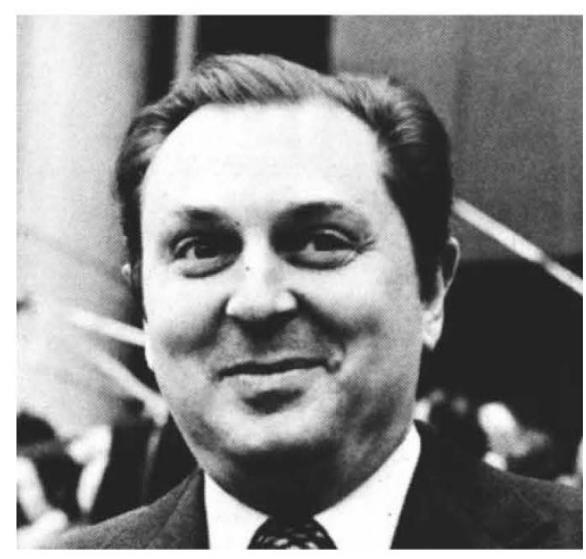

\section{Michel d'Ornano}

This proposal was strongly attacked by the DGRST: by its staff on the one hand who, like any other body, do not like the idea of being restructured by a logic they do not understand; and on the other hand by the director, Professor Curien, who distrusts dyarchies. The director was therefore moved to the CNRS. He was replaced by Bernard Grégory, who is also a former director of CERN. The Minister meanwhile stated that a technological representative will be nominated.

The proposal was also strongly attacked initially by another department, the Department of Mines. Although not implied by its title, this department is concerned with industrial research. It is the fiefdom of "mining engineers", a technocratic elite formed by the greatest of the "Grandes Ecoles", the Ecole Polytechnique. The mining engineers have an undying sense of unity: some hold high positions in the Administration, others are responsible for a large number of French industrial enterprises.

With these connections and the technical control of enterprises and industrial products that have by law fallen to it, the Department of Mines has developed a very different concept of industrial research and development from classical French practice since 1958. It is intercsted in the traditional industries; it tries to encourage collective research, common to all firms in the same sector; it checks that each project follows the objectives of the government (in conservation of energy, improvement and quality of products, working conditions and so on) through a complex series of committees. In short, it can take action effectively on scientific and technical information, industrial ownership, standardisationand on funds.

If the future technological representative does not share its philosophy, there will be serious conflicts. And the stakes are high, especially for those cnterprises which draw extensively on the research budget. 